EMILIJA NIKOLIĆ

904:725.73"652"(497.11)

Institute of Archaeology,

Belgrade, Serbia

COBISS.SR-ID 219286540

emilij@gmail.com

DRAGANA ROGIĆ

Institute of Archaeology,

Original research article

Belgrade, Serbia

Received: 25th May 2015

Accepted: November 15th 2015

BEBINA MILOVANOVIĆ

Institute of Archaeology,

Belgrade, Serbia

\title{
THE ROLE OF BRICK IN HYDRAULICITY OF VIMINACIUM MORTARS: DECORATIVE MORTARS FROM THE THERMAE*
}

\begin{abstract}
The hydraulicity of the Viminacium mortars is still somewhat unknown, but with laboratory analyses, performed on a small number of samples, and similar research performed worldwide, some conclusions can be drawn. These bring us closer to this topic, which again contribute to our becoming acquainted with the Viminacium building materials, their usage, behaviour in constructions and their mutual relationships.

Throughout history, artificial products of soil, specifically bricks and ceramics, represent some of the most commonly used materials with pozzolanic features in the creation of hydraulic lime mortars. In accordance with their function, the Viminacium thermae represent a place with high levels of humidity in the air and water in a large number of rooms, thereby representing a suitable example for analysing the use of hydraulic mortars, which above all needed to be waterproof. This was achieved with the use of bricks, a material produced locally in Viminacium.

Fragmentarily preserved remains of wall paintings from the Viminacium thermae are not only numerous and various, but they spatially also include almost all parts of the building. This paper includes the remains of decorative mortars discovered during archaeological research in 2004 and 2007 that had bricks in their structure, which was confirmed with a visual review of mortar cross-sections when brick was used in fragments. It was also suspected due to the reddish colour of some of the layers, most likely connected to the use of brick dust.
\end{abstract}

KEYWORDS: HYDRAULICITY, LIME MORTAR, BRICK, POZZOLANIC FEATURE, DECORATIVE MORTARS, THERMAE, VIMINACIUM.

\section{INTRODUCTION}

The Romans used non-hydraulic and hydraulic mortars, depending on the accessibility of the raw materials needed for their production and on their role in different constructions. Hydraulic lime mortar features can be achieved in several ways: by using quarry sand with a high percentage of

* The article results from the project: Viminacium, Roman city and military camp - research of material and non material culture of inhabitants by using the modern technologies of remote detection, geophysics, GIS, digitalisation and $3 D$ visualisation (no 47018), funded by the Ministry of Education, Science and Technological Development of the Republic of Serbia. 


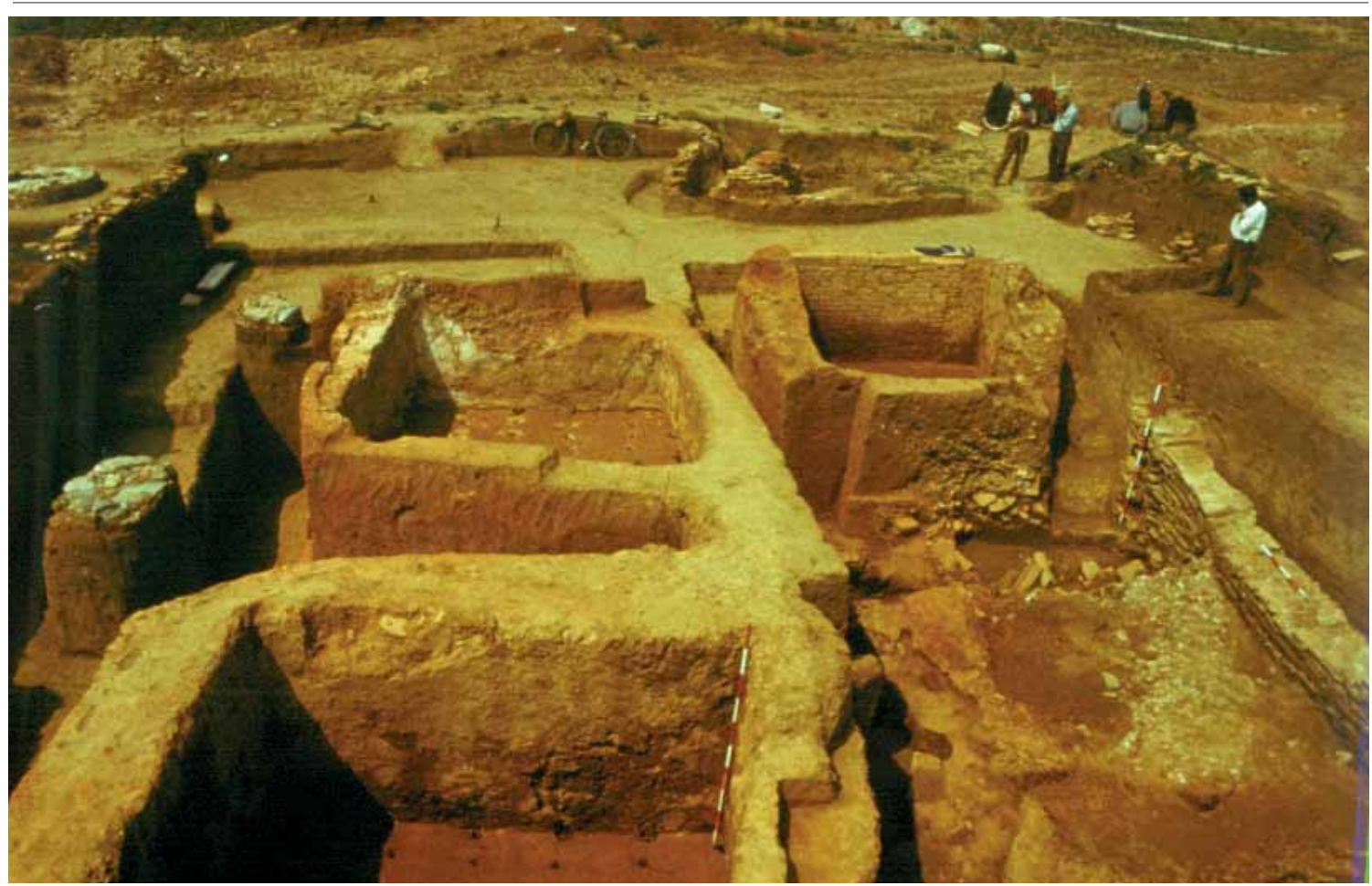

Fig. 1 Brick kils from the craftsmen's centre during excavations.

Photo-documentation of the Republic Institute for the Protection of Monuments

clay as an aggregate, natural or artificial hydraulic lime as a binder or by the use of certain materials of natural or artificial origin, with pozzolanic features, as an addition or substitute for aggregate. ${ }^{1}$

Just like artificial materials, natural materials with pozzolanic features gave hydraulicity to mortar, actually strength, water resistance and a binding possibility under water when reacting with lime. ${ }^{2}$ Nevertheless, lime mortars with the addition of natural materials set much quicker, thereby being more favourable for the building of all kinds of constructions. (Lancaster 2005: 65) Lime mortars with added brick were excellent for use in the external finishing layers, but also in all other wall or floor layers with humid and warm conditions, such as baths, (Böke et al. 2006: 1121, Elsen: 2006, 1419, Stefanidou et al. 2014: 572)

1 See Radivojević 2004: 38-39 and in Adam, 1999: 129-132.

2 It is important to distinguish between the terms "hydraulic" and "pozzolanic", since hydraulic materials can react only with water, while pozzolanic materials need both water and lime for a reaction. (Griffin 2004: 24). due to their higher resistance to water penetration. (Hale et al. 2003: 135-136) In many historical buildings, mortar was used that was made of both kinds of pozzolanic materials, depending on the accessibility of the raw materials. ${ }^{3}$

At the beginning of the $2^{\text {nd }}$ century $\mathrm{AD}$, during the "time of peace and the period of labour and economic prosperity", (Васић 1895: 29), ${ }^{4}$ Viminacium developed into a centre of brick production in this part of the Danube Limes. (Jordović 1995: 95, 105) ${ }^{5}$ (Fig. 1) Ever since that time, this building material became invaluable for wall facing, its core and levelling course, it was used independently for entire walls, indoor and outdoor floors, (Fig. 2, Fig. 3, Fig. 4, Fig. 5) and was also used as an artificial pozzolanic additive to lime mortars.

The Viminacium thermae were excavated on two occasions, from 1973 to 1974 and from 2003

3 For examples see Özkaya 2005: 76.

4 See more about this in Мирковић 1968: 64-65.

5 About craftsmen' centres for brick production in Viminacium see also Raičković 2007: 15-17 and Raičković, Redžić 2006. 


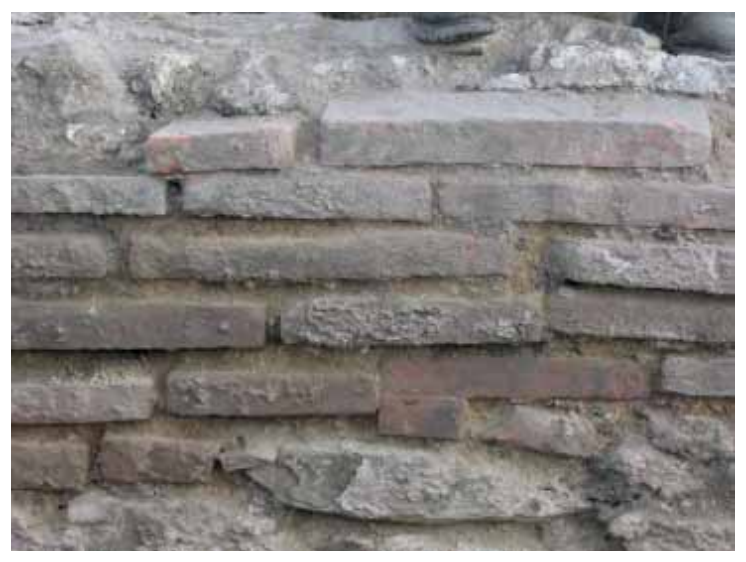

Fig. 2 Brick wall of Viminacium thermae. Photo-documentation of Institute of Archaeology Belgrade

to 2007. (Fig. 6) Both excavations revealed that there were several phases in the building of the thermae, specifically that each subsequent building was erected on the remains of the previous one. (Kondić, Zotović 1974: 96-97, Миловановић 2004: 53) The beginning of the use of the Viminacium thermae can be connected to the end of the $1^{\text {st }}$ and the beginning of the $2^{\text {nd }}$ century, whilst the building lost its primary function at the end of the $4^{\text {th }}$ century AD. (Миловановић 2004: 53; Kondić, Zotović 1974: 96-97) During the archaeological research of the Viminacium thermae, five apses were revealed, along with a central room with hypocaust and several lateral rooms. All of the building parts visible today were in use during the $3^{\text {rd }}$ and the $4^{\text {th }}$ century AD. (Миловановић 2004: 53)

\section{VIMINACIUM BRICK FEATURES AND HYDRAULICITY}

Artificial materials with pozzolanic features used throughout history include calcinated clays, slag, flying ash, ashes of rice husks, coffee husks etc. The most famous one of all is calcinated clay, presented as crushed or minced brick and ceramics. (Rapp, 2009: 266-268 и у Rossi, Russo, Russo 2009: 319-325)

Brick and ceramics are processed of easily accessible raw materials (Bugini, R. et al. 1993: 387)

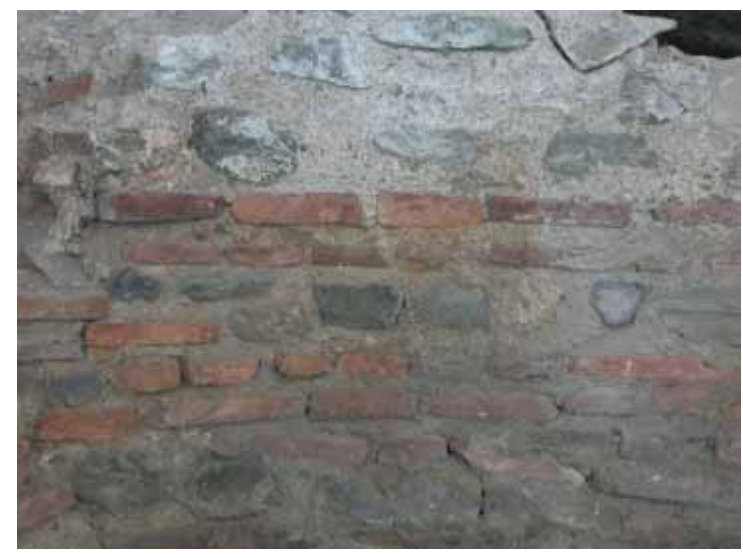

Fig. 3 Bricks in wall facing of Viminacium thermae. Photo-documentation of Institute of Archaeology Belgrade

In contrast to natural, often inaccessible materials with pozzolanic features, ${ }^{6}$ they represent the artificial materials most commonly used throughout history in all parts of the world, for producing lime mortars which required hydraulic features. In Turkey, this mortar was named horasan, in India surkhi, in Arabian countries it was called homra, (Böke et al. 2006: 1115), while in the Roman Empire its Latin name was opus signinum. (Vitruvius 2006: 144) $)^{7}$ It is best known by its Italian name cocciopesto, used in Southern Europe, while in Venice, it is also called terrazzetto. (Elsen 2006: 1419) In Minoan Crete, crushed ceramics were already being used for making lime mortars, (Moropoulou at all 2000: 50, 55, Malhotra, Mehta 1996: 3, Hughes, Sugden 2000:351, Artioli 2010: 246-248) and together with crushed brick, it was also used by the Etrurians, Hindus and the Greeks. (Malhotra, Mehta 1996: 3, Artioli 2010: 246-248)

The area of Viminacium and its vicinity belongs to the south-eastern part of the coal basin of

6 One example of the use of mortar with the addition of brick due to a lack of natural materials with pozzolanic features is Hadrian's wall, (Elsen 2006: 1419) with mortars made of lime, crushed brick, crushed sandstone, sand and the remains of baking lime from ovens, while some had animal fats as an additive. (Marie Teutonico et al. 1993: 34).

7 Vitruvius mentions opus signinum as a mortar mixture with broken bricks, tiles or pottery in the process of laying floors. 


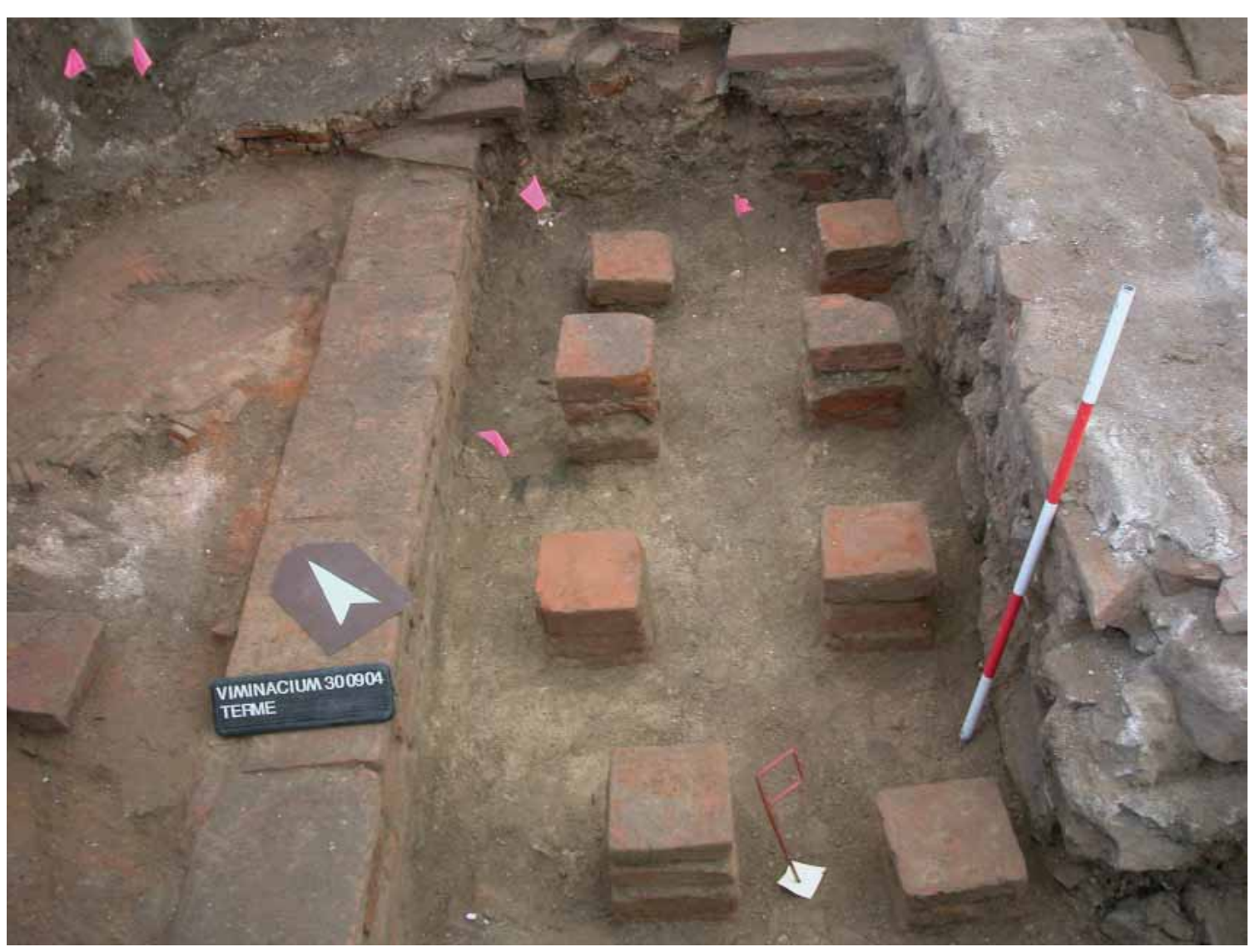

Fig. 4 Bricks of hypocaust and in wall structures of Viminacium thermae.

Photo-documentation of Institute of Archaeology Belgrade

Kostolac. The terrain's sediments consist of loess, clays, marls, sands, alevrite, pebbles, coal clays and coals. (Jovović et al. 2013: 22-26) The "large scale brick industry" (Васић 1907: 69) flourished in this Roman city due to all the accessible raw clay materials. The Viminacium builders often used brick and ceramics in mortar as an artificial material with pozzolanic features.

Nevertheless, if bricks and ceramics were to have pozzolanic features, they needed to be fired at low temperatures and contain high percentage of clay, actually to have in specific chemical composition. (Ugurlu, Boke 2009: 2443)

The firing temperatures in which bricks obtain pozzolanic features have been specified differently in different research and are measured between $600^{\circ} \mathrm{C}$ and $900^{\circ} \mathrm{C}$, (Elsen 2006: 1419, Nežerka et al. 2014, 18, (Tekín, Kurügol 2011: 959) or between $450^{\circ} \mathrm{C}$ and $800^{\circ} \mathrm{C}$. (Böke et al. 2006, 1115)
The higher the firing temperature, still within the limits stated above, the better the pozzolanic features of the bricks. (Rapp, 2009: 267) After reaching temperatures higher than $900^{\circ} \mathrm{C}$, bricks possess very limited pozzolanic features. (Pinheiro, Montenegro, Gumieri, 2010: 2) However, during the analyses of some modern samples from various European countries, it was confirmed that even after being fired at temperatures higher than $900^{\circ} \mathrm{C}$, they still possessed exceptionally high pozzolanic features. (Wild et al. 1997: 171,174)

As with all other ancient bricks from the $4^{\text {th }}$ century in the territory of Serbia, the Viminacium bricks were usually fired at temperatures up to $800^{\circ} \mathrm{C}$. (Radivojević, Kurtović-Folić 2006: 697) Laboratory sample analyses of mud mortars, discovered on brick kilns in Viminacium, showed that the temperature range reached in these kilns was between $600^{\circ} \mathrm{C}$ and $900^{\circ} \mathrm{C}$. (Raičković 2012, 


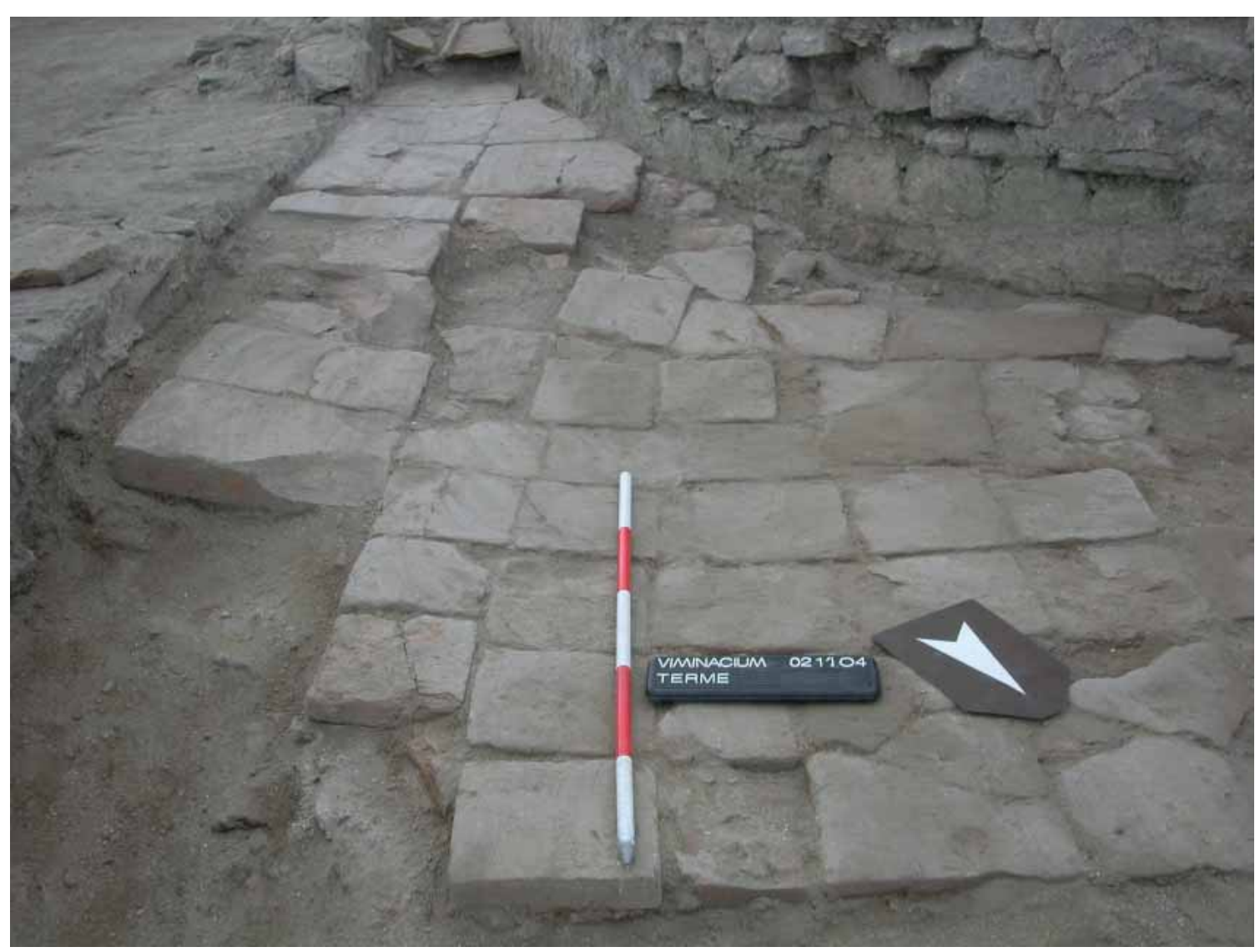

Fig. 5 Bricks as finishing floor layer in Viminacium thermae.

Photo-documentation of Institute of Archaeology Belgrade

tab.3) Based on the presence of certain minerals, analysis of Viminacium pottery fragments (Raičković 2012, tab. 2) revealed that the firing temperature of the examined samples was about $850^{\circ} \mathrm{C},{ }^{8}$ while analysis of a Viminacium building brick sample (Cornale, Moni 2007) showed that it was fired at a temperature higher than $900^{\circ} \mathrm{C}$.

The Viminacium bricks and ceramics, therefore, most likely possessed pozzolanic features, but it is certain that there were products without these features. Ancient builders empirically developed brick production techniques, since scientific explanations of the effects of temperature on a brick's features were not postulated until the beginning of the $20^{\text {th }}$ century. (Tekín, Kurügol 2011: 960) Nevertheless, it is likely that ancient builders were capable of recognising products suitable

8 According to analogue research Barlueng et al. 2013:214-216. for certain needs. Supporting the use of specific bricks, there are analyses of mortars with added bricks and bricks themselves from Ottoman baths of the $14^{\text {th }}$ and $15^{\text {th }}$ century. They showed that brick fragments used in mortars possess high pozzolanic activity, while bricks used for construction possess different levels of the activity. This could indicate that bricks with pozzolanic features were deliberately chosen for the production of hydraulic mortars and probably they were recognised only because they contained more clay minerals. (Böke et al. 2006: 1121) The use in mortar of bricks possibly fired at very high temperatures and certain ceramic types fired at such temperatures was most likely only aiming to improve the aggregate mass and the mortar's mechanical features, while pozzolanic features were embedded only in those fragments originating from products which fulfilled the conditions mentioned above. 


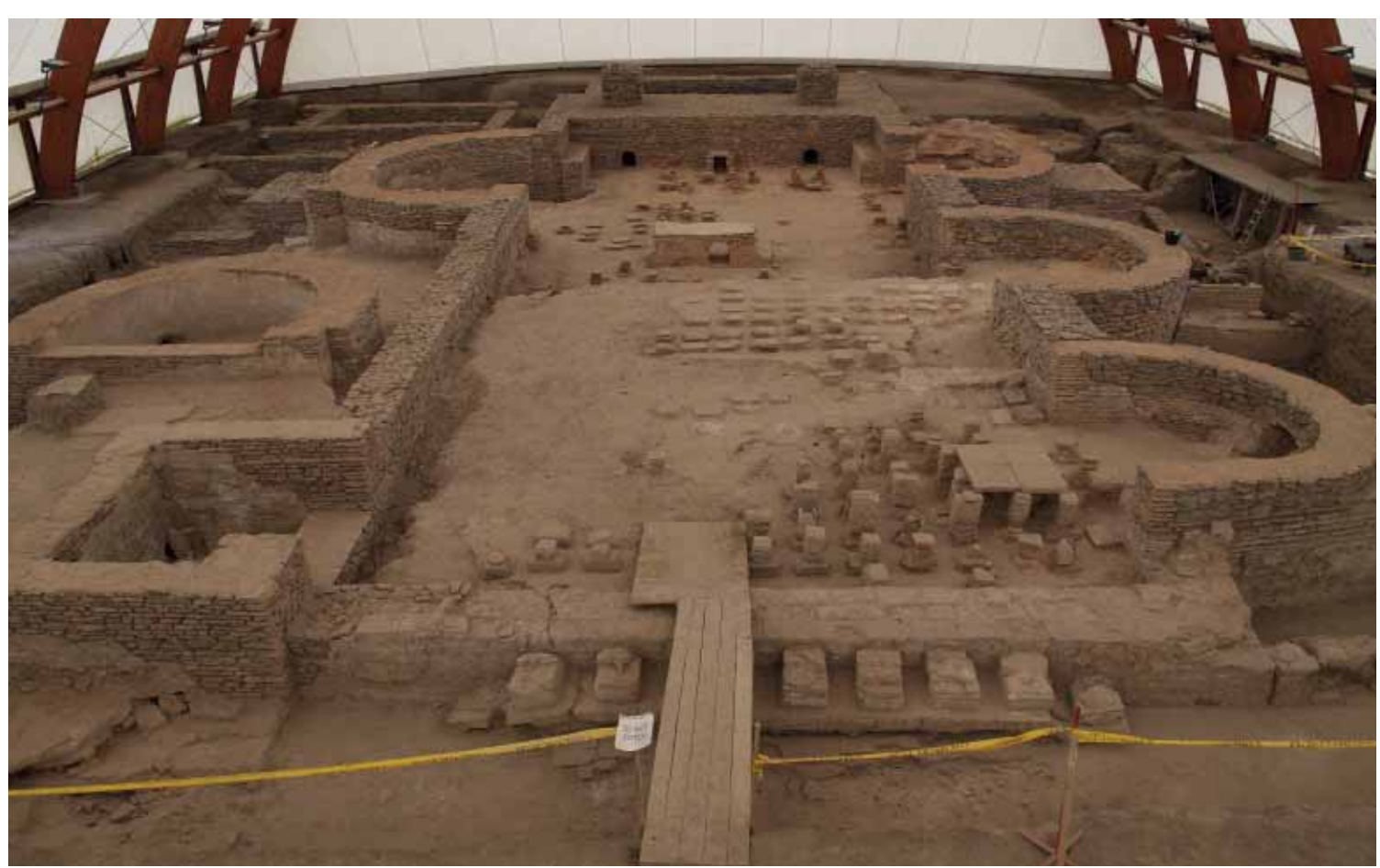

Fig. 6 View of Viminacium thermae today. Photo-documentation of Institute of Archaeology Belgrade

According to international standards, the sum of percentages of the oxide content of $\mathrm{SiO}_{2}, \mathrm{Al}_{2} \mathrm{O}_{3}$ and $\mathrm{Fe}_{2} \mathrm{O}_{3}$ in natural pozzolanic materials, but also in brick products with pozzolanic features, should be higher than 70\%. (ASTM C618-12a: 2012, Pinheiro, Montenegro, Gumieri 2010: 2) The total content of the oxides $\mathrm{SiO}_{2}, \mathrm{Al}_{2} \mathrm{O}_{3}$ and $\mathrm{Fe}_{2} \mathrm{O}_{3}$ in a brick sample from a Viminacium tomb from the $4^{\text {th }}$ century is $85.10 \%$. (Radivojević, Kurtović-Folić 2006: 698) The shard analysis from various Viminacium vessels showed that the total amount of the mentioned oxides does not exceed $70 \%$ only in $8 \%$ of the samples, while in some samples it reaches as high as $90 \%$. (Raičković 2012, tabs.47) The total of the oxides $\mathrm{SiO}_{2}, \mathrm{Al}_{2} \mathrm{O}_{3}$ and $\mathrm{Fe}_{2} \mathrm{O}_{3}$ in mud mortar used to build a brick kiln, in all of the samples exceeded $70 \%$, and in one of them as high as $90.25 \%$ (Raičković 2012, tab.8), indicating the soil structure and the technology for making building materials from it.

It is interesting to mention a natural creation, known locally as "crvenka", which, in the form of a red, brown, black and ochre layer, can easily be noticed in the profiles of the nearby hills of the villages around Viminacium, in which there was a underground coal mine during the $19^{\text {th }}$ and the $20^{\text {th }}$ century. ${ }^{9}$ (Fig. 7, Fig. 8) This represents layers of sedimentary rocks which experienced a metamorphosis caused by the combustion of the lower coal layers. Coal could be ignited in a natural way, by spontaneous combustion when coming into contact with oxygen or a lightning strike or a fire caused by some human factor, (Murphy: 2013: 2-3) which is often encountered worldwide under different names, the most common of which are clinker and porcellanite. ${ }^{10}$ "Crvenka" was used by the Romans of Viminacium in road and wall core structures $^{11}$ (Fig. 9, Fig. 10) and, in accordance

9 About this mining see Мајовски Вучетић 2010, and about red clay see also Nikolić 2013: 27-28.

10 See examples from Romania: Rădan, Rădan 2011: 266-270, Czechia: Žáček, Skála, Dvořák 2010: 1-32 and USA: Murphy 2013: 2-4 and Rogers 1917: 1-10. 11 Regarding the use of "crvenka" in Viminacium buildings see Golubović, Korać 2008: 33-36 and Nikolić, Bogdanović 2012: 43-44. Even in modern times, clinker is used as the final layer on roads without asphalt in areas where there are no pebbles and where clinker represents the hardest rock. See U.S. 


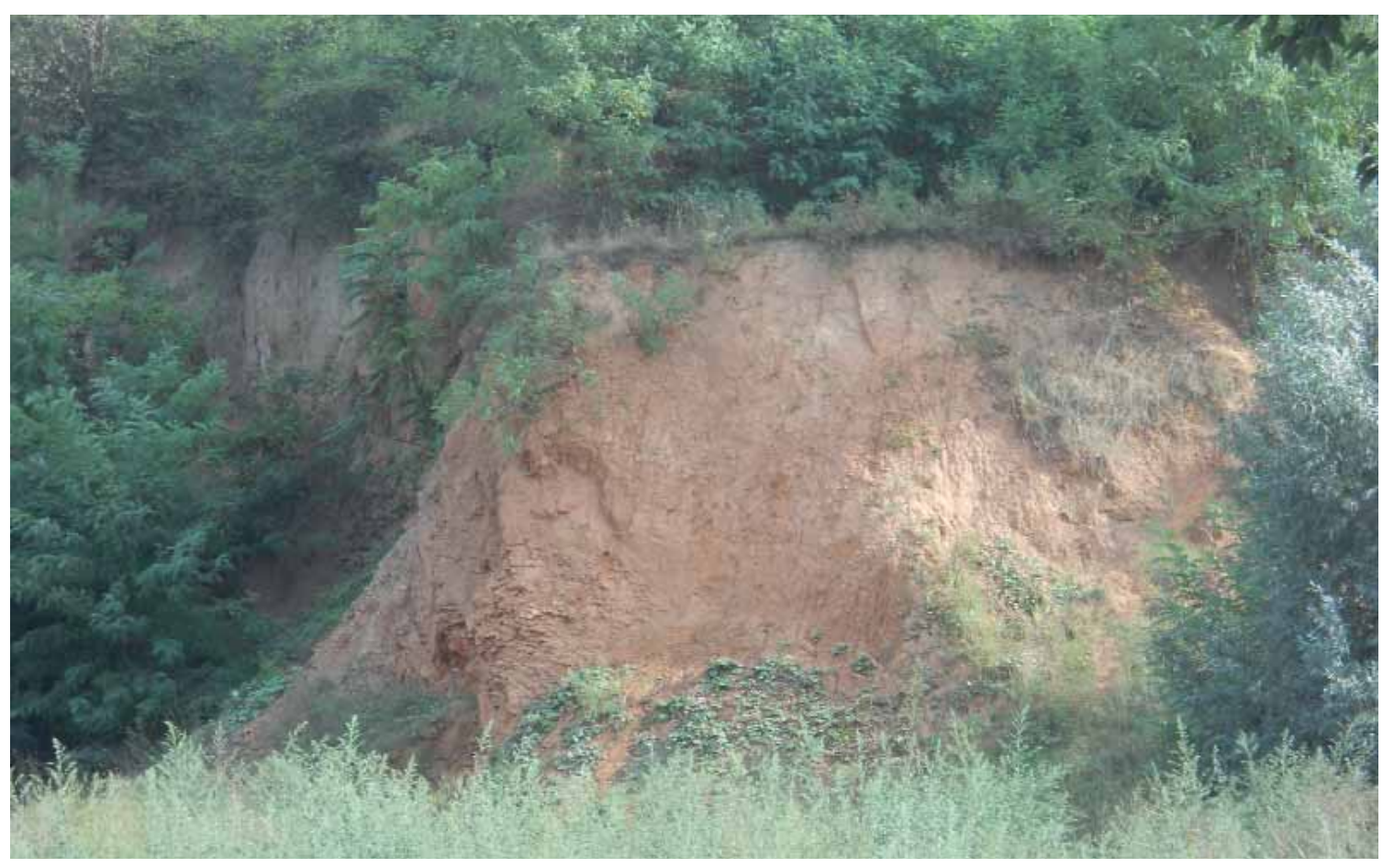

Fig. 7 Hill above Stari Kostolac village with visible red layer of „crvenka“. Photo by the authors

with its role in construction, was in the shape of larger or smaller, more or less fired pieces.

Depending on the firing temperature, "crvenka" could be a partially coherent and very poriferous rock, reminiscent of slag from a blast furnace when it is closer to a source of high temperature, but also a material similar to brick, when it is formed at lower temperatures. (de Boer, Dekkers, van Hoof 2001: 94) In southern England, mosaic tesserae have been found and plates in the opus sectile technique, originating from several Roman buildings and made of these naturally fired rocks, from the second half of the $1^{\text {st }}$ and the beginning of the $2^{\text {nd }}$ century AD. Such decorations belong to early Roman mosaics in this territory and there are also indications that there were workshops introducing clinker into elements of interior finishing. (Allen, Fulford 2004: 9-38) These materials were therefore accessible to all the social strata, military, public and private. The largest use of "crvenka" in Viminacium can be placed into the same chronological frame, in the time of the still undeveloped

Dept. of the Interior, Bureau of Land Management, 1984: 61 and Murphy: 2013: 2. brick industry, but also during later periods of crisis, given that it was most likely a cheap and easily accessible material. (Nikolić 2013: 28)

Worldwide research has already established the pozzolanic features of this natural creation (Jevtić, Zakić, Harak 2002: 60; Gutt, Gaze, 1975: 439-450, Ríos, Williams, 2008: 2482-2492), depending on its creation conditions, the firing temperature and the classification of the primary rocks. If future research about the local "crvenka" reveals its pozzolanic features, and knowing already the "rule" regarding the use of local materials in Roman architecture, ${ }^{12}$ the use of "crvenka" as a pozzolanic addition to lime mortars in Viminacium buildings could be examined. The red colour of Viminacium mortars could then be ascribed to the added brick or ceramics, as well as to the addition of "crvenka". As an example from a region of Romania with a similar geological structure shows, high temperatures during the firing of the original clay leads to the formation of new minerals in fired clays, such as hematite (Rădan,

12 Regarding this see also Radivojević, Kurtović-Folić 2006: 693. 


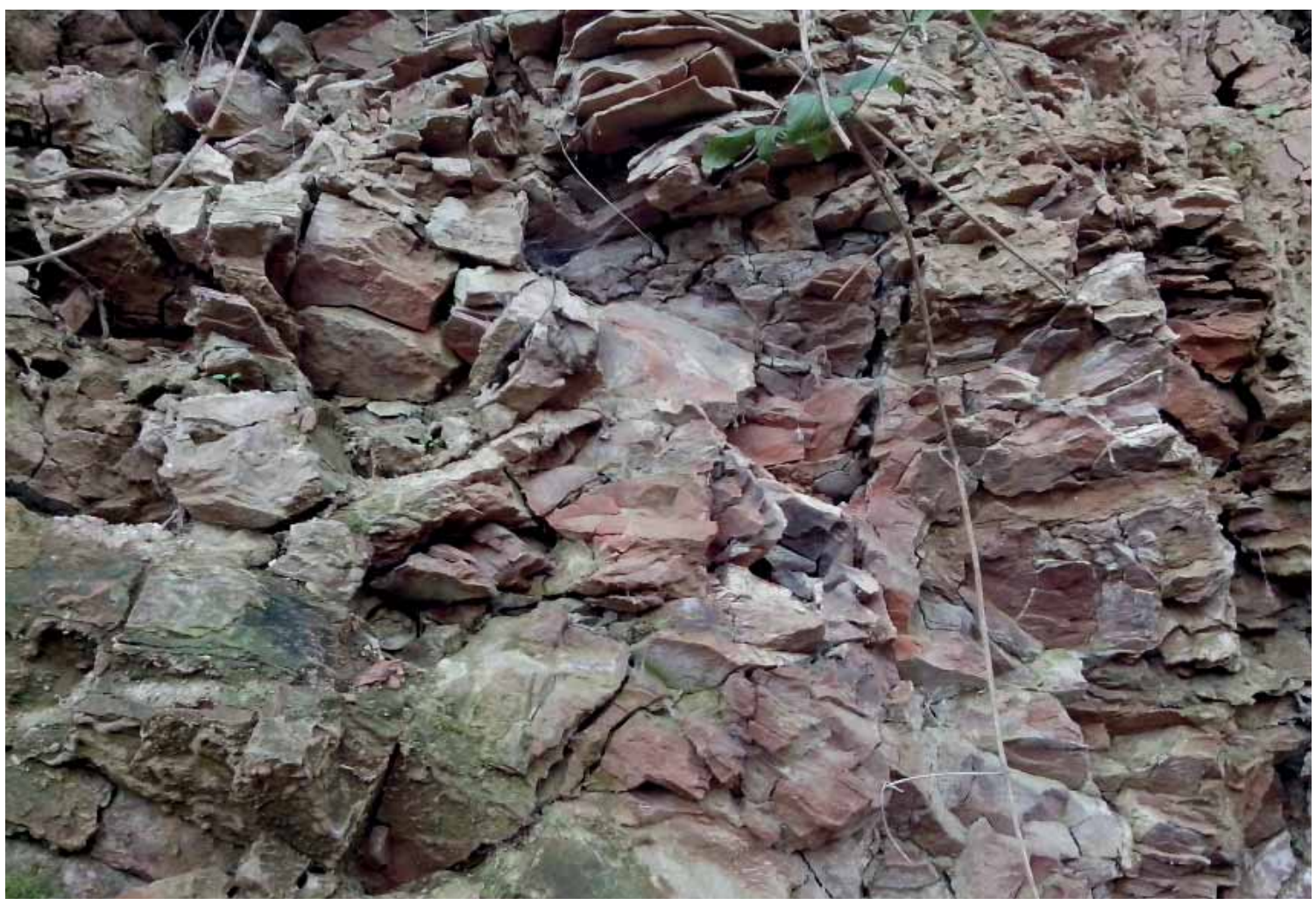

Fig. 8 Hill above Stari Kostolac village with visible red layer of „crvenka“, detail. Photo by the authors

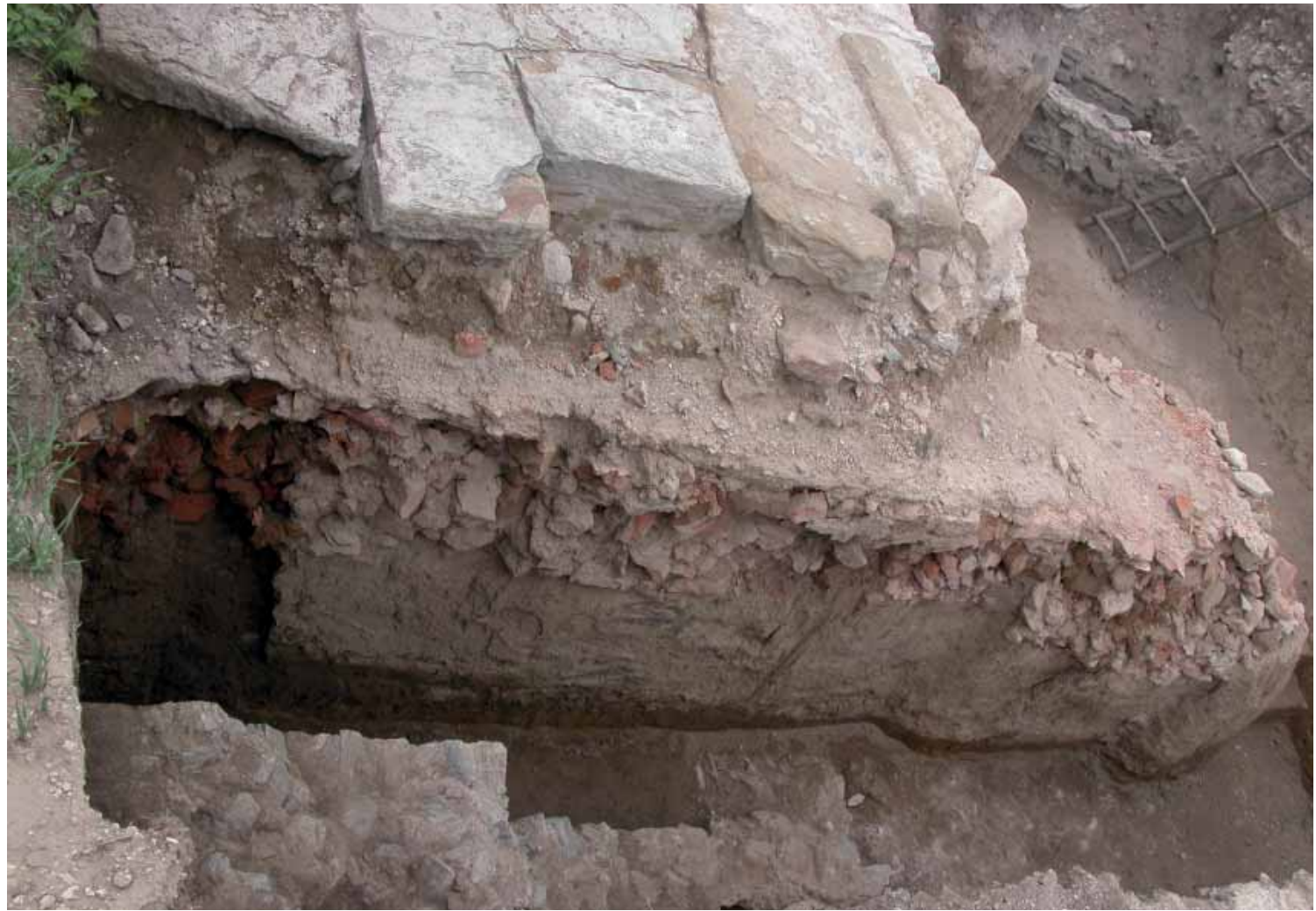

Fig. 9 Part of the early gate tower partially destroyed by the later road entering the northern gate of the legionary fort. Photo-documentation of Institute of Archaeology Belgrade 


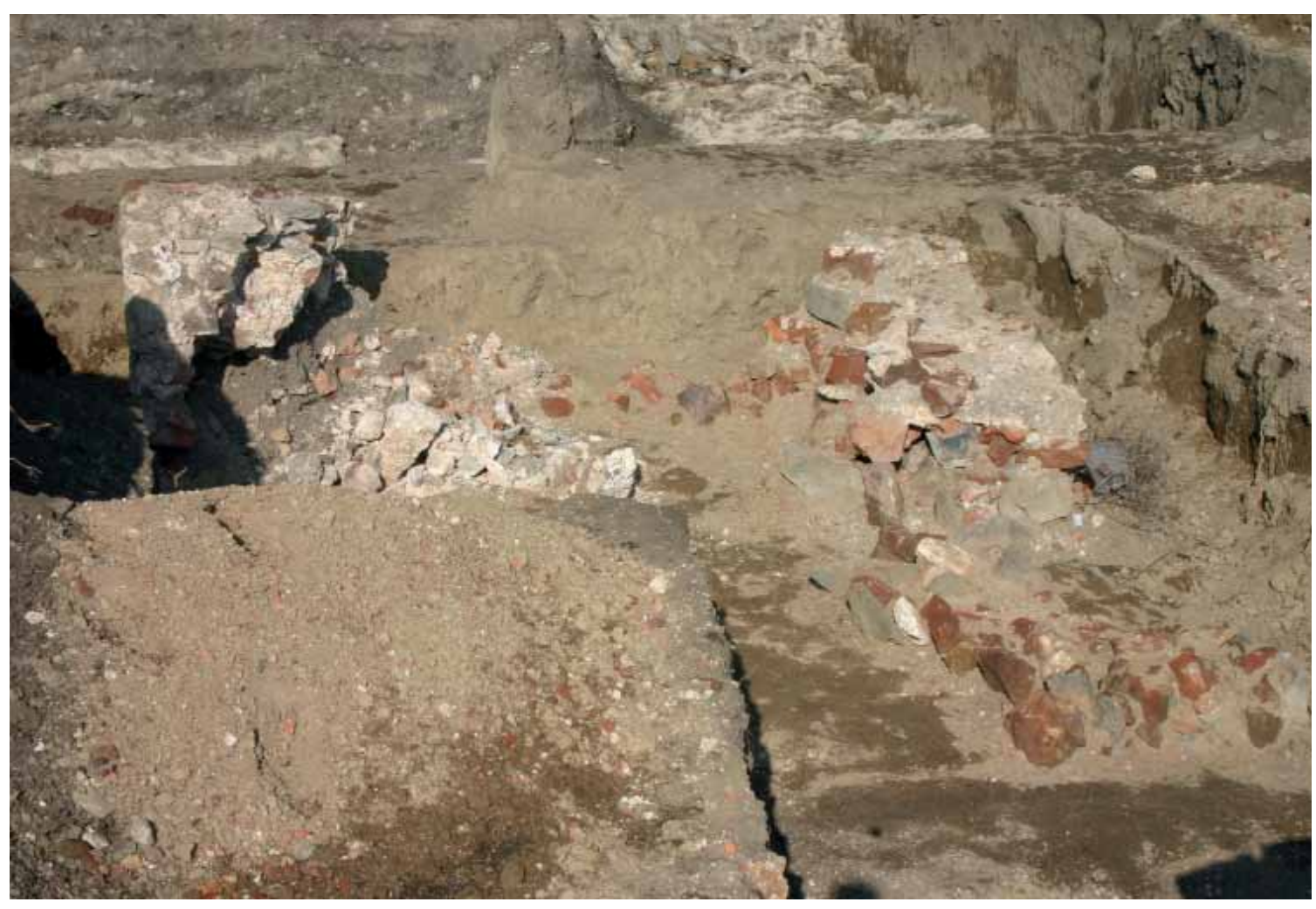

Fig. 10 Foundation structure from the bulding in the temple complex with visible „crvenka“. Photo-documentation of Institute of Archaeology Belgrade

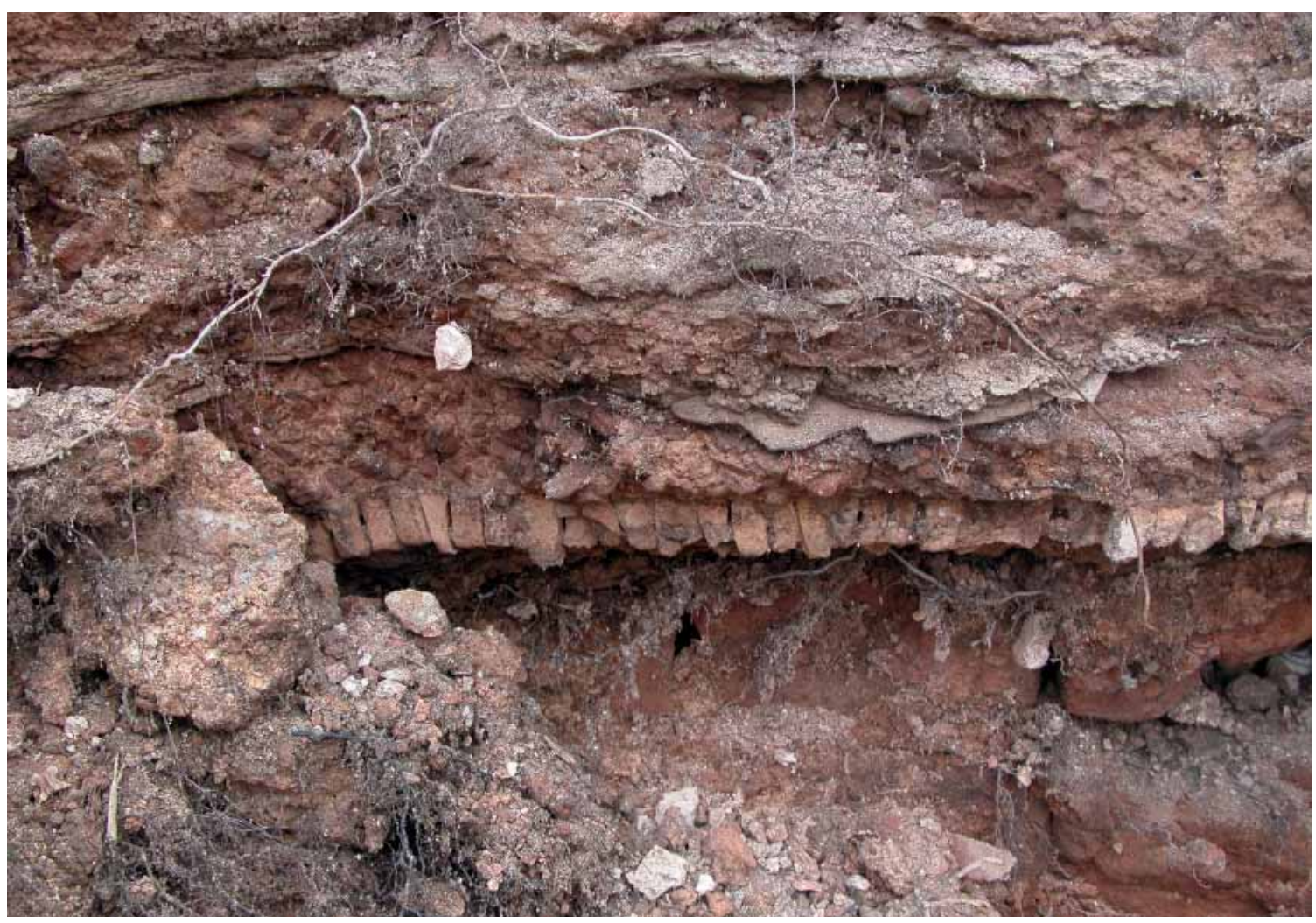

Fig. 11 Floor layers of Viminacium thermae with brick in the form of large fragments. Photo-documentation of Institute of Archaeology Belgrade 
Rădan 2011b: 267-268, Rădan, Rădan 2011a: 147), a natural source of several, most commonly red, pigments. (Walsh, Chaplin 2008: 189)

\section{THE ROLE OF BRICK IN VIMINACIUM MORTARS}

Even by only visually examining the Viminacium mortar samples used for masonry, rendering and plastering, one can notice differences in the mortar structure and brick admixture, indicating that Roman builders were well-acquainted with the preparation of mortar with specific features. (Bugini et al. 1993: 386) In structural mortars, lower mortar layers of floor constructions and mortars for rendering, brick admixture is visible in the mortar structure in the form of smaller or larger fragments, (Fig. 11, Fig. 12) while in those mortars used for, plastering, wall-paintings and finishing floor layers, the brick appears in the form of small fragments, but also in the form of a dust. (Fig. 13, Fig. 14) The dust was integrated with lime, with or without a sand admixture, and gave the mortar a red appearance, especially noticeable when the mortar was polished.

In areas where there were no natural materials with pozzolanic features, brick played an important role in the structure of mortars used for construction. Nevertheless, for economic reasons, lime mortar without any admixtures was often used, while the use of structural mortar with brick admixtures was limited to more important, public and even monumental constructions. Probably the most successful example of the use of brick in structural mortar is Hagia Sophia in Istanbul. The mortar joints were very wide, comparing to the width of the bricks. This mortar, made with brick dust and brick fragments, can be called a proto-concrete. (Livingston, R.A. et al. 1992: 721-736)

This rule of economy applied by ancient builders is also visible in an example from a completely different area, from a much earlier era and with admixtures of other materials, on the buildings of ancient Olynthus, from the $4^{\text {th }}$ century BC. Here, for economic reasons, mud mortar was used for building stone walls exposed to humidity, after which the walls were rendered with hydraulic mortars ${ }^{13}$. Furthermore, in examples of Roman structures in France containing fresh water, the frequent use of brick admixtures can be noticed in mortars used for plastering and different floor layers, while the use of such mortars for building walls is somewhat rare (Coutelas 2011:147). Mortars used in supporting constructions do not need to make walls water-resistant. Brick and ceramic admixtures, therefore, appear also in mortars used for walls not directly connected to water containing structures, with the function of protecting the inner wall surfaces from external humidity factors. (Degryse et al. 2002: 1459).

After examining the material from the Viminacium thermae, it is easily understood that mortar with a brick admixture was always applied in structures that required humidity- and water-resistance, specifically in floors and outer wall layers, (Fig. 15, Fig. 16) as well as in mortars used for plastering and rendering pools and canals but, very rarely, as a structural mortar.

\section{BRICK IN DECORATIVE MOR- TARS OF THE THERMAE}

This paper also deals with the remains of mortar used for plastering and rendering the thermae walls, mostly painted or decorated afterwards and, therefore, also referred to as decorative mortars, which were discovered during archaeological research in 2004 and 2007..$^{14}$ (Fig. 17). Some of these decorative mortars were applied directly on

13 Information provided by Prof. Dr Ioanna Papayianni and Ass. Prof. Dr Maria Stefanidou (Laboratory of Building Materials, Civil Engineering Department AUTH, Greece), during the lecture "Case Study: Olynthos, Chalkidiki” (MARE 14 Workshop) where an author of this paper participated.

14 About fragment restoration see more in Rogić, Despotović, Milovanović 2009: 75-81. 


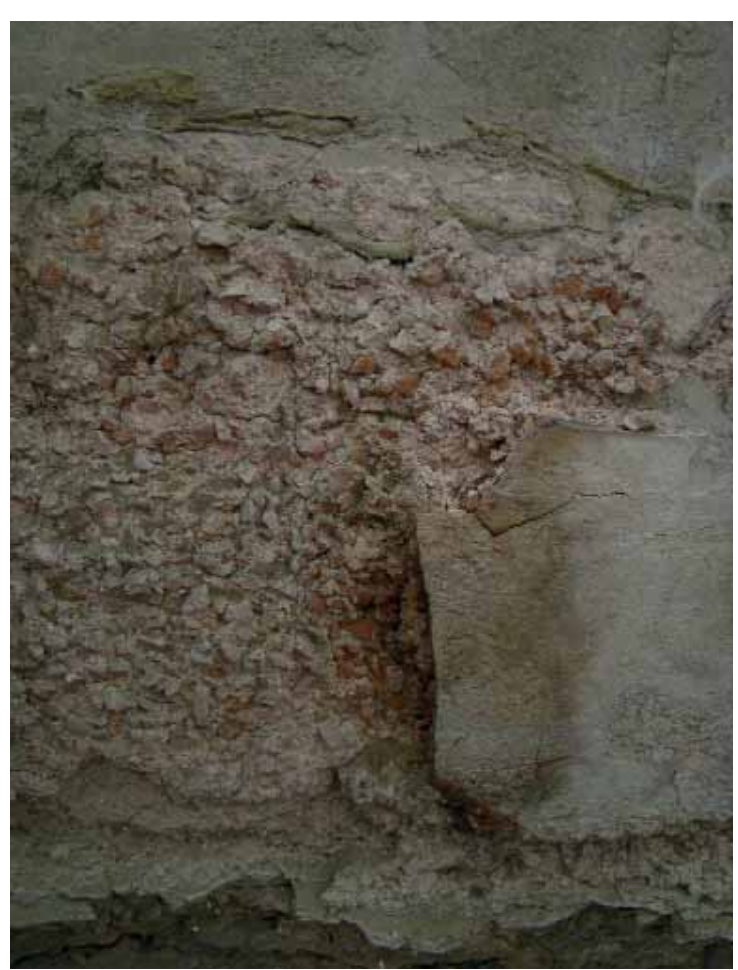

Fig. 12 Rendering layers of Viminacium thermae with brick in the form of large fragments.

Photo-documentation of Institute of Archaeology Belgrade

the walls, but some of them were executed onto a first layer of plaster or render (preparing layer or leveling layer). It depended on the state of a wall and on the material a wall structure was built of.

Brick admixtures served multiple roles in decorative mortars. According to some authors, as well as making mortar hydraulic or waterproof as an artificial material with pozzolanic features, it also absorbed humidity, therefore enabling painters a longer working period when applying the fresco technique. The painting basis needed to be humid enough and brick admixtures delayed the process of water loss or evaporation, thereby slowing drying (Šulić, 2010: 3). It can be connected to the thesis that "brick ground" (brick wall) "absorbs superfluous water, and keeps the plaster much longer in a fit state for painting upon." (Taylor, 1843: 38). Also, it is important to notice that the contact between brick and fresh mortar causes water transport, but also depends on the relationship between dimensions of the pores of both

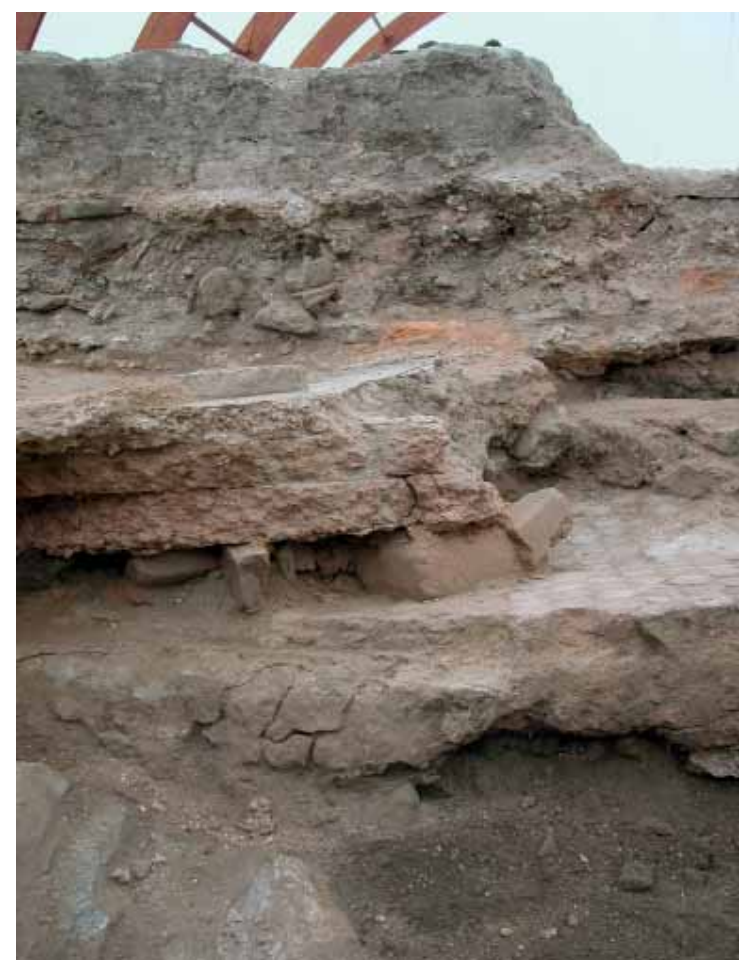

Fig. 13 Floor layers of Viminacium thermae with brick in the form of small fragments and in the form of a dust.

Photo-documentation of Institute of Archaeology Belgrade

materials. (Groot 1997:122) It is interesting to mention that mortars containing natural pozzolana were probably not used as a support for fresco painting, which was the most often applied technique in Viminacium thermae. It is impossible to get a good adherence of the pigments when painting on the mortar containing natural pozzolana, which is the result of different chemical reactions. (Bläuer Böhm 2000: 111)

After analysing painted decorations from Roman villas in Hungary, it was noticed that quite often, over the intonaco, but prior to the painting layer, a pinkish layer was applied, made of brick powder. It can be concluded that this was a "rule" in the period in which they were constructed, specifically the end of the $1^{\text {st }}$ and during the $2^{\text {nd }}$ century $\mathrm{AD}$, with the aim of offering water-proofness and protection of the painted layer from water or humidity from the wall. (Kirchoff 2008: 251-254) In mortars without a painted layer and as part of the intonaco, brick often produced a reddish or 


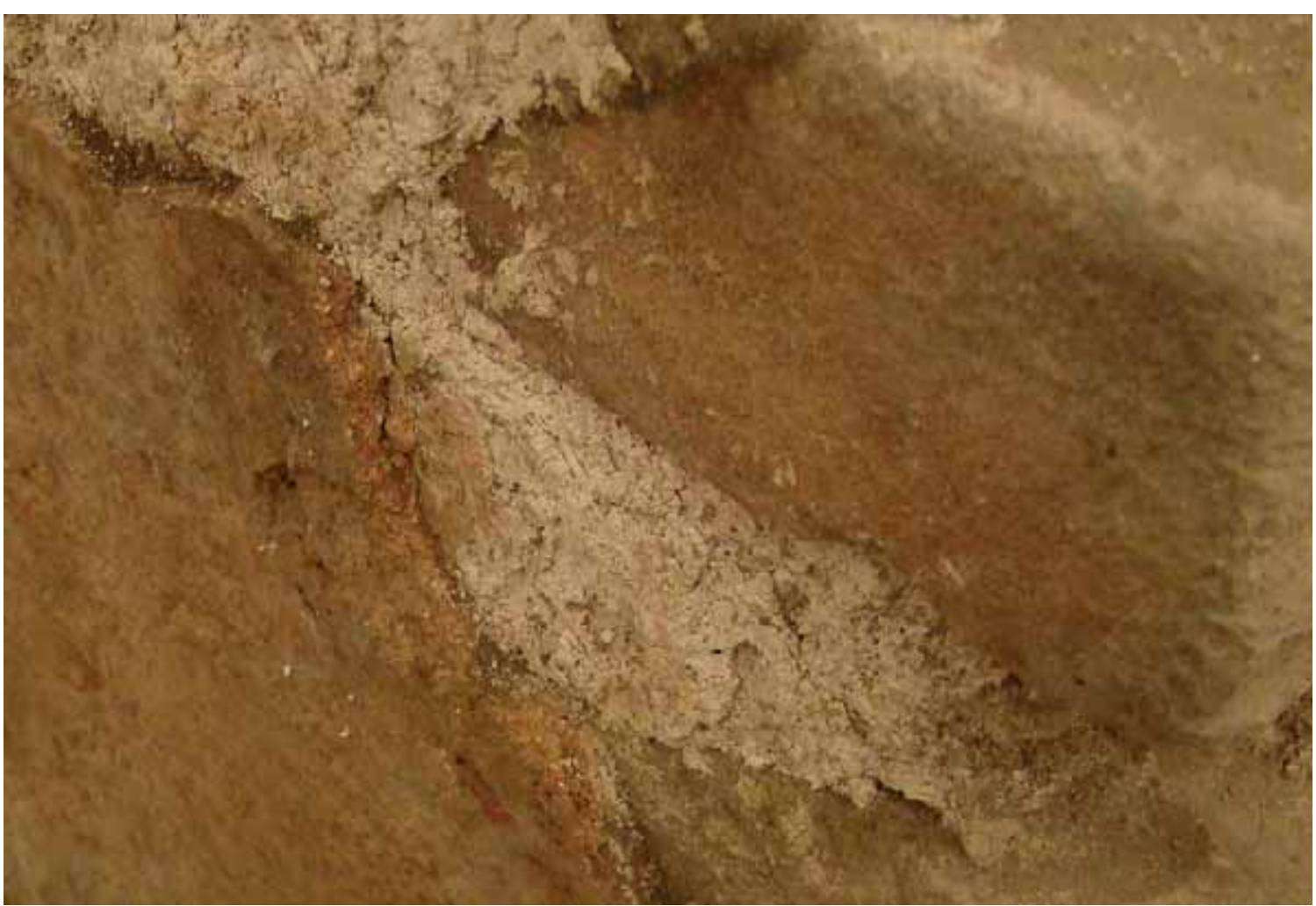

Fig. 14 Rendering layers of Viminacium thermae with brick in the form of small fragments and in the form of a dust. Photo-documentation of Institute of Archaeology Belgrade

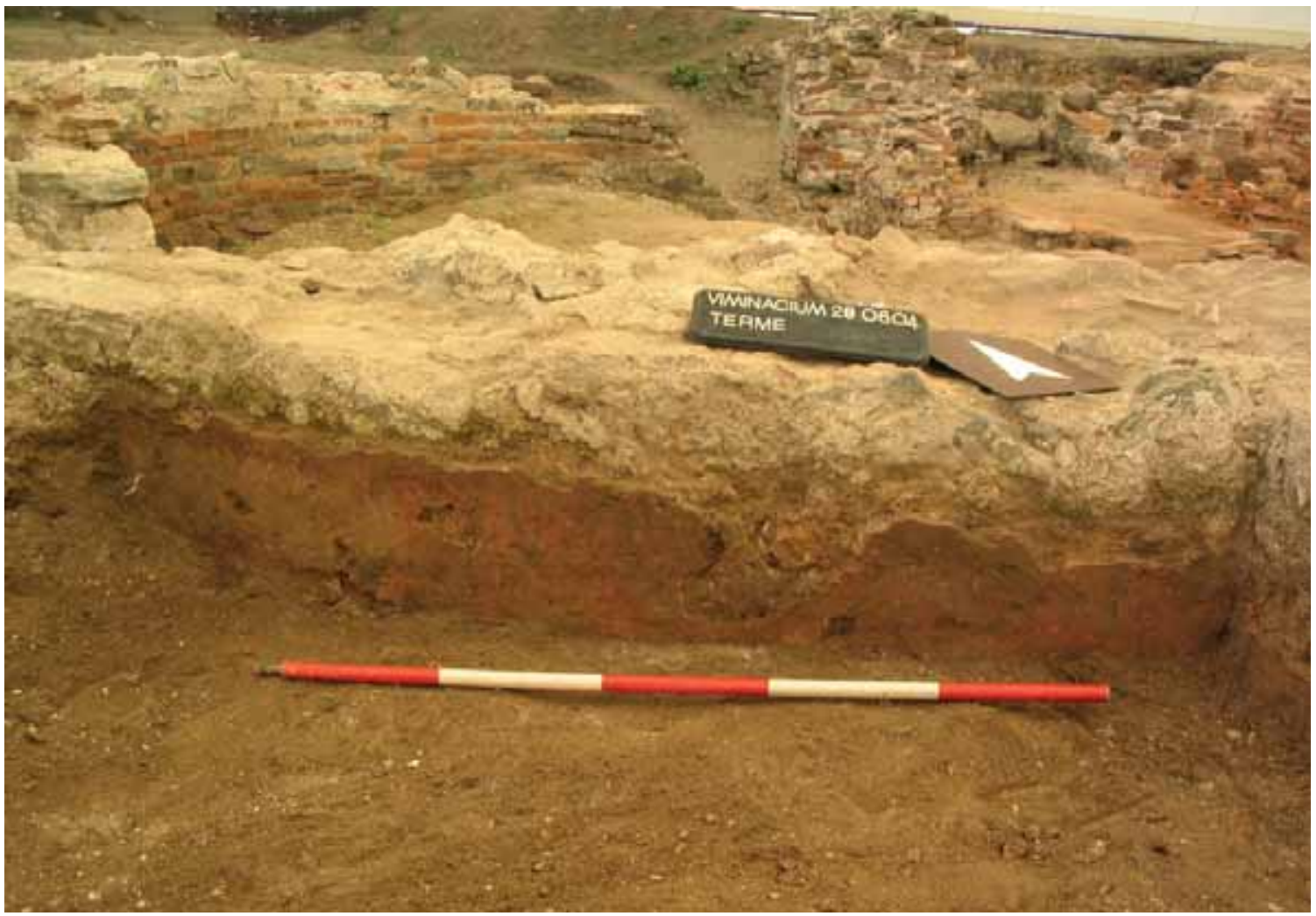

Fig. 15 Outer wall of Viminacium thermae, with red mortar having brick in its structure. Photo-documentation of Institute of Archaeology Belgrade 


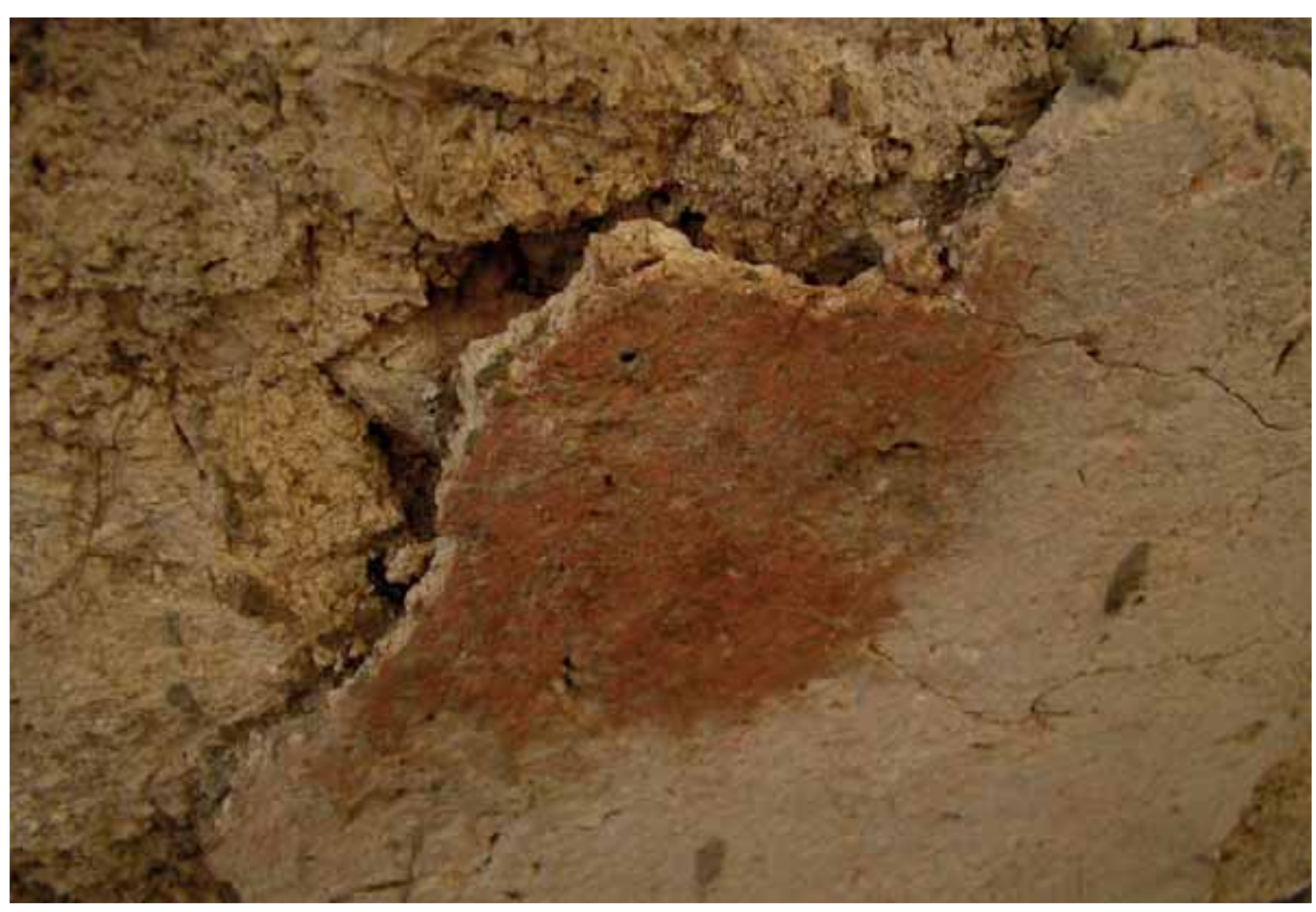

Fig. 16 Outer wall of Viminacium thermae, with red mortar having brick in its structure, detail. Photo-documentation of Institute of Archaeology Belgrade

pinkish colour. (Wiseman, Zisi 2014: 185)

Based on the amount and the form of the brick admixtures in decorative mortar layers (in arriccio and intonaco), the fragments from the Viminacium thermae can be divided into four groups. (Table 1 and Table 2) Brick was here mostly used as a dust, but also in the form of smaller fragments. The largest number of fragments belongs to the third group.

First group. The first mortar group, which includes fragments in which only the intonaco contained brick dust can most likely be ascribed to mortars for internal decorative plastering, for colouring and painting walls in rooms in which humidity was more or less concentrated, but not in rooms with water present in larger amounts. The role of this kind of mortar was to secure rooms and walls from humidity penetration. With mortars in this group, it can be noticed that the arriccio or intonaco were rather thick.

With some mortars, without a painted layer, the reddish intonaco layers with brick dust are visible. Here, the intonaco colour serves a decorative purpose. There are also mortars with a "reddish intonaco" 15 painted red and additionally polished, with the aggregate of these mortars having been finely sieved.

Second group. The second mortar group includes fragments in which only the arriccio contains brick powder, probably used as decorative mortars on walls of rooms in which there was no permanent presence of humidity or water. The presence of brick in the arriccio is explained with the risk of possible humidity and water penetration into the wall from the background, as in the case of walls built without bricks and where there is no mortar layer with brick content. (Wiseman, Zisi 2014: 167) These fragments can therefore be ascribed to the inner surfaces of outer walls or the opposite sides of walls that possessed one side exposed to the aforementioned agents.

Third group. The third mortar group, with dust or fragments in both layers, includes mortars used as painting bases, monochrome or with motifs, and 15 Mortars with aggregates of brick dust. 

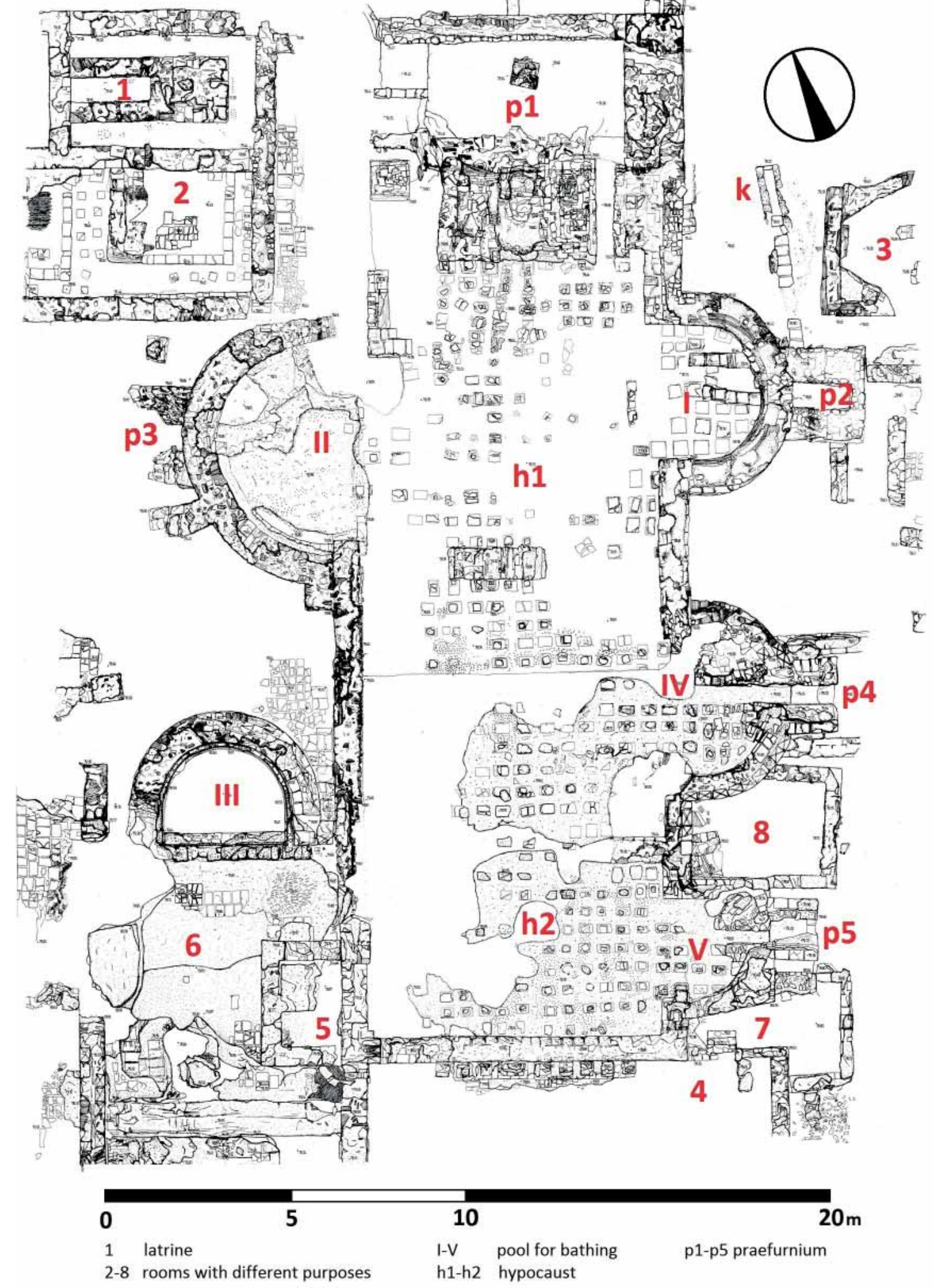

Fig. 17 Layout of Viminacium thermae.

Photo-documentation of Institute of Archaeology Belgrade 
as mortars without a painted layer, where the colour was determined by the brick in the intonaco's structure. These mortars were most likely on walls exposed to water, specifically the walls of bathing pools and the outer faces of external building walls.

In this mortar group, pieces can be noticed that possess a thicker intonaco and a thinner arriccio. They most likely represent mortars of reduced quality, indicated by a small fragment compacity and a huge number of pores formed over time.

Fragments containing larger brick pieces in the arriccio were probably used for rendering outer building walls, since brick in this form gives mortar a greater resistance to weather conditions. The thickest arriccio layers contain the largest brick fragments. Examination of Roman mortars from Hadrian's Wall showed that the use of smaller particles of bricks creates strong hydraulic mortars, since such particles possess high pozzolanic features, while larger particles act more as a porous addition absorbing air into the mortar, therefore making it more resistant to frost and salt crystallisation. This means that mortars used for external rendering, with the aim of increasing frost resistance, should contain particles of larger dimensions. (Teutonico et al, 1993:41-42)

Fourth group. The fourth mortar group should be considered as mortars used for rendering external building walls, or building facades, with a single, thicker mortar layer and without a painted layer. Due to atmospheric influences, it was necessary for the mortar to contain bricks in its entire structure, here in the form of dust, thus giving hydraulic features, namely endurance and setting in water. Due to the colour of the brick, it possessed a red finish, hence considered a decorative mortar.

\section{CONCLUSION}

In the case of decorative mortars from the Viminacium thermae, brick was mostly used for ensuring resistance and setting mortar under water and in humid conditions, in contrast to the use of brick in structural mortars, where it was used mostly to ensure a hydraulicity which would make the mortar stronger. Regarding the mortar fragments discussed in this paper, it is clear that the artists involved in the painting of the thermae were well-acquainted with the purpose of brick in mortar and applied it properly, whilst sometimes using mortars of reduced quality, leaving them porous and less compact.

Preserved fragments of the thermae wall paintings were not only numerous and various, but also spread throughout the building. Although they alone can not offer any data about the decoration of the Viminacium thermae, a huge difference in technology and painting quality can be noticed. There are red polished surfaces, reddish unpolished surfaces without a painted layer, dark blue and dark purple painted polished surfaces with decoration, as well as white intonaco backgrounds without a painted layer, with or without decoration on them. It seems that a huge number of the thermae walls were reddish in colour, originating from the intonaco with brick admixture and no painted layer.

After analysing the role of brick in the hydraulicity of the Viminacium mortars and its application through the examples of adding it to the decorative mortars of the Viminacium thermae, this paper tends to show that many conclusions regarding a historic building can be drawn directly from the analysis of the building materials. The function of rooms and the role of the construction elements of a building depended very much on the materials applied and vice versa. Examining a building is therefore not to be separated from becoming acquainted with the materials and technologies used for their processing and application both during the building process itself, and after. 


\section{BIBLIOGRAPHY}

Adam, J. P. 1999

Roman Building:Materials And Techniques (1989), (trans.) Anthony Matthews, London: Routledge.

Allen, J. R. L., and Fulford, M. G. 2004

Early Roman Mosaic Materials in Southern Britain, with Particular Reference to Silchester (Calleva Atrebatum): A Regional Geological Perspective, Britannia 35: 9-38.

Artioli, G. 2010

Scientific Methods and Cultural Heritage: An Introduction to Application of Materials Science to Archaeometry and Conservation Science, New York: Oxford University Press, Inc.

\section{ASTM C618-12a, 2012}

Standard Specification for Coal Fly Ash and Raw or Calcined Natural Pozzolan for Use in Concrete, Active Standard ASTM C618 | Developed by Subcommittee: C09.24 Book of Standards Volume, 04.02.

\section{Barluenga, G. et al. 2013}

Bricks and mortars from the "Patio de Santo Tomás", Alcalá University (Madrid, Spain): A combined study of fabric characterization and building morphology". In: Science and Technology for the Conservation of Cultural Heritage, (eds. M. A. Rogerio-Candelera, M. Lazzari and E. Cano. London: CRC Press: 213-216.

\section{Bläuer Böhm, C. 2000}

Analyses of mortars containing pozzolanas", in: Historic Mortars: Characteristics and Tests: Proceedings of the International RILEM Workshop, (eds.) P. Bartos, C. Groot, J. J. Hughes. Bagneux: RILEM Publications s.a.r.1.: 105-112.

Böke, H. et al. 2006

Characteristics of brick used as aggregate in his- toric brick-lime mortars and plasters, Cement and Concrete Research 36: 1115-1122.

\section{Bugini, R. et al. 1993}

Investigation of the characteristics and properties of "cocciopesto" from the ancient roman period, in: Conservation of stone and other materials. Vol.1: causes of disorders and diagnosis, Proceedings of the international RILEM/UNESCO congress held at the UNESCO headquarters in Paris, June 29 - July 1, 1993, London: E. \& F.N. Spon: 386-393.

\section{Cornale, P. and Monni, E. 2007}

Sito Archaeologico di Viminacium, Serbia: Analisi mineralogico-petrografica e chimico-fisica, relazione scientifica, Vicenza: CSG Palladio srl.

\section{Coutelas, A. 2011}

The selection and use of lime mortars on the building sites of Roman Gaul, Commentationes Litterarum Humanarum 128: 139-151.

\section{De Boer, C. B., Dekkers, M. J., and van Hoof,} T. A. M. 2001

Rock-magnetic properties of TRM carrying baked and molten rocks straddling burnt coal seams, Physics of the Earth and Planetary Interiors 126: 93-108.

\section{Degryse, P., Elsen, J. and Waelkens, M. 2002}

Study of ancient mortars from Sagalassos (Turkey) in view of their conservation, Cement and Concrete Research 32: 1457-1463.

\section{Elsen, J. 2006}

Microscopy of historic mortars - a review, $\mathrm{Ce}$ ment and Concrete Research 36: 1416-1424.

\section{Golubović, S. and Korać, M. 2008}

The Recent Discovery of a Temple Complex at Viminacium, Roma 2008 - International Congress of Classical Archaeology: Meeting Between Cultures In the Ancient Mediterranean 
http://151.12.58.75/archeologia/bao_document/ poster/5_Golubovic_Korac.pdf (accessed September, 17th 2014).

\section{Griffin, I. 2004}

Pozzolanas as additives for grouts: An investigation of their working properties and Performance Characteristics, Studies in Conservation 49/1: 2334.

\section{Groot, C. 1997}

Initial Rate of Absorption and Porosity, PRO 3: International RILEM Workshop on Evaluation and Strengthening of Existing Masonry Structures, RILEM Proceedings, (eds.) L.Binda, C.Modena, Bagneux: RILEM Publications s.a.r.1.: 117-125.

\section{Gutt, W., Gaze, M. E. 1975}

Trinidad porcellanite as a pozzolan, Materials and Structures, Vol. 8, No. 6: 439-450.

\section{Hale et al. 2003}

Dating ancient mortar: Although radiocarbon dating is usually applied to organic remains, recent work shows that it can also reveal the age of some inorganic building materials, American Scientist 91: 130-137.

\section{Hughes, D.C., Sugden D.B. 2000}

The use of brick dust as a pozzolanic addition to hydraulic lime mortars, Historic Mortars: Characteristics and Tests: Proceedings of the International RILEM Workshop, (eds. P. Bartos, C. Groot, J. J. Hughes, Bagneux: RILEM Publications s.a.r.1.: 351-360.

Jevtić, D., Zakić, D. i Harak, S. 2002

Ispitivanje različitih tipova maltera spravljenih na bazi opekarskog loma, Materijali i konstrukcije 45: 60-63.

\section{Jordović, Č. 1994}

Grnčarski i ciglarski centar u Viminacijumu, $S a$ opštenja XXVI: 95-106.

\section{Jovović, A. et al. 2013}

Studija o proceni uticaja na životnu sredinu za projekat izgradnje novog bloka B3 na lokaciji TE Kostolac B. Beograd: Univerzitet u Beogradu, Mašinski fakultet, Univerzitet u Beogradu, Rudarsko-geološki fakultet.

\section{Kirchoff, A. 2008}

Ab ovo ad mala: The decorative system and reconstruction of the Red Dining Room at Baláca, Balácai Közlemények X, Veszprém: Dezso Laczko Museum: 42-111.

\section{Kondić, V., Zotović, Lj. 1974}

Viminacium - rezultati arheoloških istraživanja u 1974. godini, Arheološki pregled 16, Beograd: Savez arheoloških društava Jugoslavije: 94-97.

\section{Lancaster, L. C. 2005}

Concrete Vaulted Construction in Imperial Rome: Innovations in Context, New York: Cambridge University Press.

\section{Livingston, R.A. et al. 1992}

Preliminary analysis of the masonry of the Hagia Sophia Basilica, Istanbul, in: Materials Issues in Art and Archaeology III, Materials Res. Soc. Symp. Proc., vol. 267, (eds.) P.Vandiver et al., Pittsburgh: Materials Research Society, pp.721-736.

\section{Malhotra, V. M. and Mehta, P. K. 1996}

Pozzolanic and Cementitious Materials, Amsterdam: Gordon and Breach Publishers.

\section{Миловановић, Б. 2004.}

Извештај са систематских археолошких ископавања на локалитету Терме - Виминацијум 2004. године, Археолошки преглед н.с. 2/3 (2004/5), Београд: Министарство културе Републике Србије и Српско археолошко друштво: 51-54.

\section{Mirković, M. 1968}

Rimski gradovi na Dunavu u Gornjoj Meziji, Beograd: Arheološko društvo Jugoslavije. 
Moropoulou, A., Bakolas, A. and Bisbikou, K. 2000

Investigation of the technology of historic mortars, Journal of Cultural Heritage 1, Amsterdam: Elsevier: 45-58.

\section{Murphy, E. C. 2013}

Clinker ("scoria") as Road Surfacing Material in Western North Dakota, Geonews 40/1, Bismarck: North Dakota industrial commission, Department of mineral resources: $2-4$.

\section{Nežerka, V. et al. 2014}

Comprehensive study on mechanical properties of lime-based pastes with additions of metakaolin and brick dust, Cement and Concrete Research 64: 17-29.

\section{Nikolić, E. 2013}

Contribution to the study of Roman architecture in Viminacium: Construction materials and building techniques, Archaeology and Science 8, Belgrade: Center for New Technology and Archaeological Institute Belgrade: 21-48.

\section{Nikolić, S., i Bogdanović, I. 2012}

Istraživanja viminacijumskog amfiteatra $\mathrm{u}$ toku 2011. Godine, in: Arheologija u Srbiji: Projekti Arheološkog instituta u 2011. Godini, (eds.) V. Bikić, S. Golubović, D. Antonović, Beograd: Arheološki institut: 42-46.

\section{Özkaya, Ö.A. 2005}

Properties of Roman brick and mortars used in Serapis temple in Bergama, A Thesis Submitted to the Graduate School of Engineering and Sciences of İzmir Institute of Technology in Partial Fulfillment of the Requirements for the Degree of Master of Science.

Pinheiro, I. S., Montenegro, L. C., Gumieri, A. G. 2010

Pozzolanic activity of recycled red ceramic bricks, Proceedings from Second International Conference on Sustainable Construction Materi- als and Technologies, Università Politecnica delle Marche, Ancona, Italy, 28-30 June, 2010, Vol. 1. Milwaukee: UWM Center for By-Products Utilization: 299-308.

\section{Rădan, S. C. and Rădan, S. 2011a}

How coal fires affect the clays: an interdisciplinary approach, in: Fire Effects on Soil Properties, Proceedings of the $3^{\text {rd International Meeting on }}$ Fire Effects on Soil Properties, Guimarães, 1519 March, 2011 (eds.) António Bento Gonçalves, António Vieira. Guimarães: NIGP-Univ. Minho and CEGOT: 148-152.

\section{Rădan, S.C., Rădan.S, 2011b}

Coal palaeofires in the western Dacic Basin (Romania): geophysical, mineralogical and geochemical signatures recovered from porcelanites and clinkers; a case history, in: Fire Effects on Soil Properties, Proceedings of the 3rd International Meeting on Fire Effects on Soil Properties, Guimarães, 15-19 March, 2011, (eds.) António Bento Gonçalves, António Vieira. Guimarães: NIGP-Univ. Minho and CEGOT: 266-270.

\section{Radivojević, A. 2004}

Konstrukcije i tehnike građenja antičkog Rima, Beograd: Orion Art.

\section{Radivojević, A. and Kurtović-Folić, N. 2006}

Evolution of Bricks and Brick Masonry in the Early History of Its Use in the Region of Today's Serbia, Journal of Materials in Civil Engineering 18, Special issue: Innovative Materials and Technologies for Construction and Restoration. Reston: American Society of Civil Engineers: 692-699.

\section{Raičković, A. 2007}

Keramičke posude Zanatskog centra iz Viminacijuma, Arheologija i prirodne nauke, Posebna izdanja 3, Beograd: Centar za nove tehnologije Viminacium i Arheološki institut. 


\section{Raičković, A. i Redžić, S. 2006}

Keramičarske i opekarske peći Viminacijuma Lokacije Pećine i Livade kod Ćuprije, Arheologija i prirodne nauke 1, Beograd: Centar za nove tehnologije Viminacium i Arheološki institut.

\section{Raičković, A. 2012}

Keramičke posude iz grobova tipa Mala Kopašnica Sase, Unpublished PhD thesis. Defended at Faculty of Philosophy, University of Belgrade.

\section{Rapp, G. 2009}

Archaeomineralogy, Berlin: Springer.

\section{Ríos, , C.A., Williams, C.D. 2008}

Synthesis of zeolitic materials from natural clinker: A new alternative for recycling coal combustion by-products, Fuel 87. Amsterdam: Elsevier: 2482-2492.

\section{Rogers, G.S. 1917}

Baked shale and slag formed by the burning of coal beds. Professional paper 108-A, Washington: Department of the Interior and United States Geological Survey.

Rogić, D., Despotović, D., Milovanović, B. 2008 Fragmenti zidnog slikarstva sa termi Viminacijuma, Arheologija i prirodne nauke 3, Beograd: Centar za nove tehnologije Viminacium i Arheološki institut: 75-81.

\section{Rossi, C., Russo, F., Russo, F. 2009}

Ancient Engineers' Inventions: Precursors of the Present, Berlin: Springer.

\section{Stefanidou et al. 2014}

Analysis and characterization of hydraulic mortars from ancient cisterns and baths in Greece, Materials and Structures 47, Berlin: Springer: 571-580.

\section{Šulić, V. 2010}

Restoration plaster for the wall paintings presentations in three Pre-Romanesque churches on the
Adriatic coast, Proceedings from 2nd Conference on Historic Mortars - HMC 2010 and RILEM TC 203-RHM final workshop. Eds. J. Válek, C. Groot and J.J. Hughes. Bagneux: RILEM Publications s.a.r.1.: $723-732$.

\section{Taylor, W.B.S. 1843}

A Manual of Fresco and Encaustic Painting: Containing Ample Instructions for Executing Works of These Descriptions. With an Historical Memoir of These Arts from the Earliest Periods, Oxford: Chapman \& Hill.

\section{Tekín, Ç., Kurügol, S. 2011}

Physicochemical and pozzolanic properties of the bricks used in certain historic buildings in Anatolia, Gazi University Journal of Science 24 (4), Ankara: Gazi University: 959-972.

\section{Teutonico, J.M. et al. 1993}

The Smeaton project: Factors affecting the properties of lime-based mortars, APT Bulletin 25/3/4, Spingfield: Association for preservation technology international (APT): 32-49.

\section{Uğurlu, E., Böke, H. 2009}

The use of brick-lime plasters and their relevance to climatic conditions of historic bath buildings, Construction and Building Materials 23, Amsterdam: Elsevier: 2442-2450.

\section{U. S. Dept. of the Interior, Bureau of Land Man-} agement. Powder River Resource Area, 1984

Powder River Resource Area resource management plan: Miles City District, Ann Arbor: The University of Michigan.

\section{Васић, М. 1895}

Колонија Виминацијум: археолошка студија, Старинар XII, Београд: Српско археолошки друштво: 1-61.

\section{Vitruvije, 2006}

Deset knjiga o arhitekturi. Trans. R. Jadrešin- 
Milić, Beograd: Građevinska knjiga.

Вучетић, М. 2010

Из историје српских угљенокопа: Јаме костолачког мајдана, Београд: ЈП Електропривреда Србије.

Walsh, V., Chaplin, T. 2008

Pigment Compendium: A Dictionary and Optical Microscopy of Historical Pigments, London: Routledge.

\section{Wild, S. et al. 1997}

Pozzolanic properties of a variety of European clay bricks: Comparative study of pozzolanic, chemical and physical properties of clay bricks in four European countries for utilization of pulverized waste clay brick in production of mortar and concrete, Building Research and Information 25/3, London: Routledge: 170-175.

\section{Wiseman, J., Georgievski, Đ. 2014}

"Wall decoration at Stobi". In: Studies in the Antiquities of Stobi, vol. 2. (1983). (eds. and trans.) J. Wiseman and Đ. Mano-Zisi, Princeton: Princeton University Press: 163-189.

\section{Žáček, V., Skála, R., and Dvořák, Z. 2010}

"Petrologie amineralogie porcelanitů mostecké pánve - produktůfosilních požárů neogénní hnědouhelné sloje". Bulletin mineralogicko-petrologického oddělení Ná-rodního muzea v Praze 18/1. Praha: National Museum / Národní muzeum: 1-32.

\section{ACKNOWLEDGEMENTS}

Authors of the paper thank Dr Angelina Raičković Savić for permission to use laboratory results from her unpublished $\mathrm{PhD}$ thesis (Raičković, A. 2012) during the research for this paper.

\section{REZIME \\ ULOGA OPEKE U HIDRAULIČNO- STI MALTERA VIMINACIJU- MA: DEKORATIVNI MALTERI GRAĐEVINE TERMI}

KLJUČNE REČI: HIDRAULIČNOST, KREČNI MALTER, OPEKA, PUCOLANSKO SVOJSTVO, DEKORATIVNI MALTERI, TERME, VIMINACIJUM.

Viminacijumske terme su, s obzirom na veliku koncentraciju vlage $u$ vazduhu, česte izmene temperature i prisustvo većih količina vode u pojedinim prostorijama, analizirane kroz upotrebu krečnih maltera sa dodatkom opeke. Oni su korišćeni za malterisanje i dekoraciju zidova, a opeci su dugovali postojanost u vlazi i vodi, odnosno hidrauličnost.

Prisustvo opeke u dekorativnim malterima se potvrđuje vizuelnim pregledom preseka maltera kada je opeka korišćena u fragmentima, ali i naslućuje kod crvene boje pojedinih slojeva koja verovatno potiče od prisustva mlevene opeke.

Prema količini i obliku opeke prisutne u ariču i intonaku, dekorativne maltere građevine termi možemo podeliti u četiri grupe. Prvu grupu bi činili malteri gde je prisustvo opeke zabeleženo $\mathrm{u}$ intonaku, druga grupa obuhvata one fragmente gde se opeka nalazi u sastavu ariča, u treću grupu spadaju malteri gde oba malterna sloja sadrže opeku, a četvrta grupa predstavlja maltere izvedene u jednom sloju sa agregatom od opeke.

Analiza fragmenata dekorativnog slikarstva termi Viminacijuma navodi na zaključak da veliki broj zidova termi nije bio obojen, već da je svoju crvenkastu boju dugovao prisustvu opeke u intonaku. Ovde se vidi kako su Rimljani Viminacijuma uspešno primenili pravilo rimske arhitekture o upotrebi lokalnih materijala. Osim što je bila nosilac hidrauličnosti i vodonepropusnosti kod maltera za zidanje i malterisanje, opeka je kod dekorativnih maltera termi Viminacijuma bila i deo podloge, kao što im je davala boju i teksturu, odnosno njegov konačni izgled. 


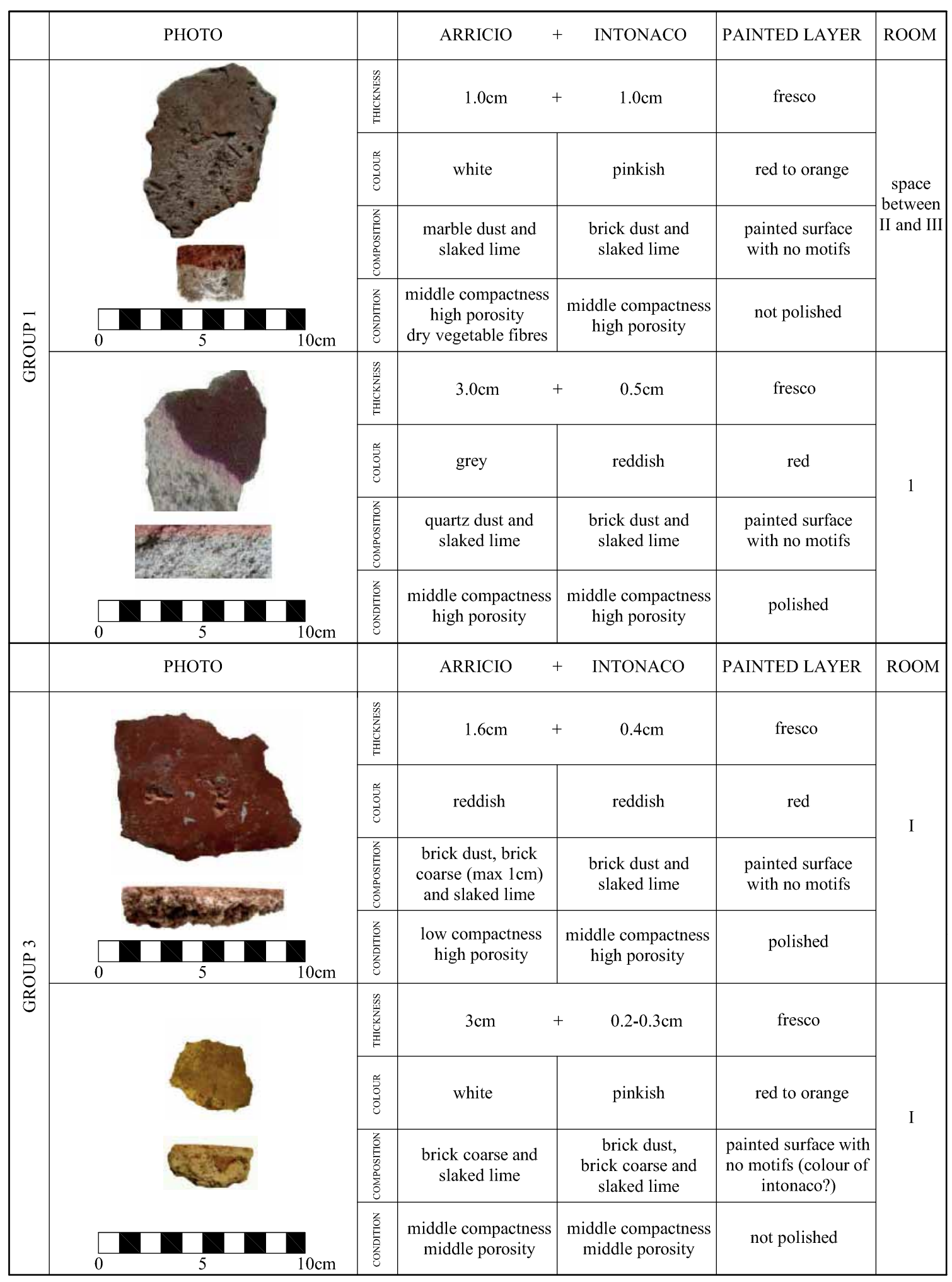

Table 1 Fragments of decorative mortars from the Viminacium thermae divided into groups. Photo-documentation of Institute of Archaeology Belgrade. 


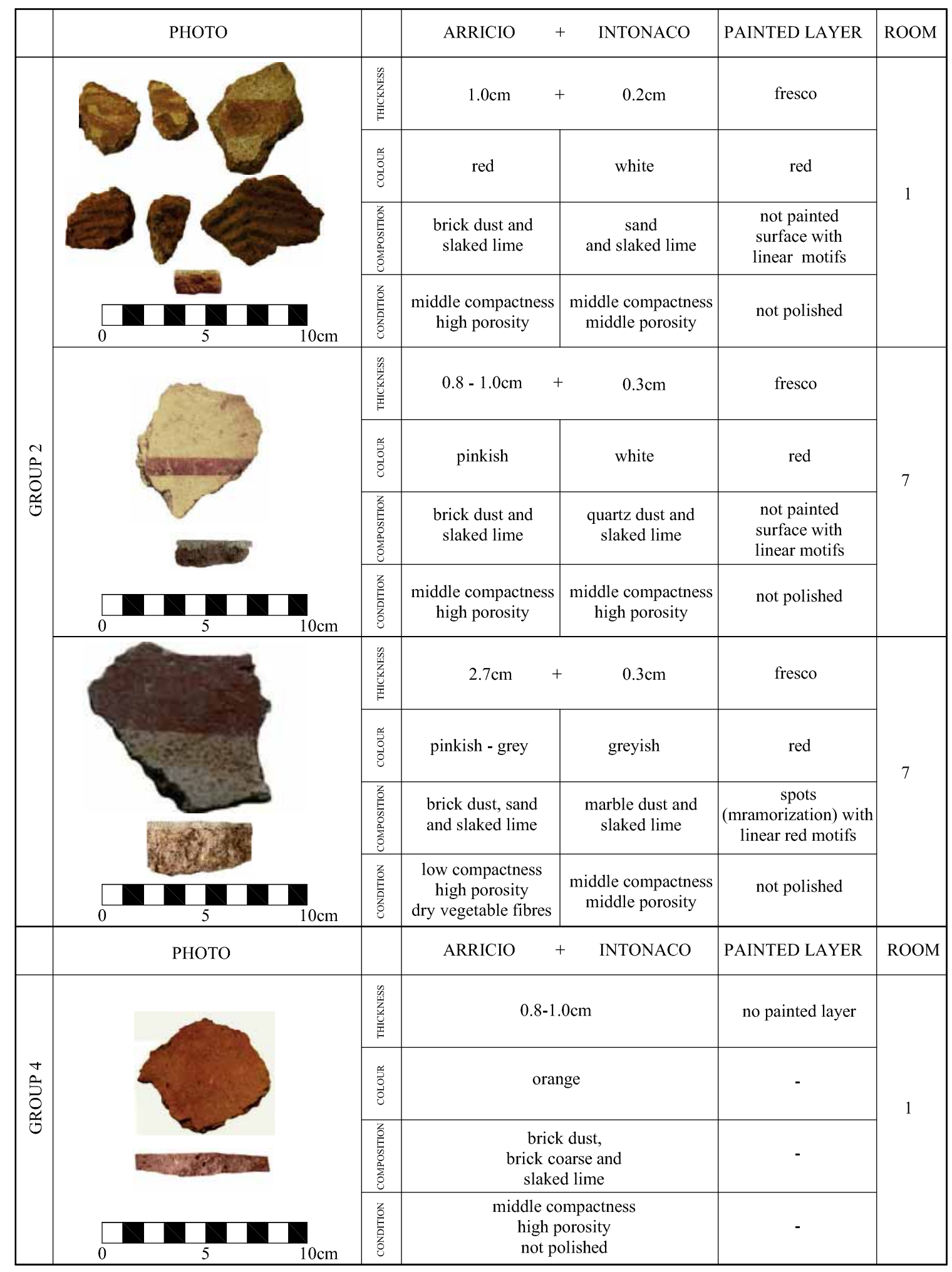

Table 2 Fragments of decorative mortars from the Viminacium thermae divided into groups. Photo-documentation of Institute of Archaeology Belgrade. 